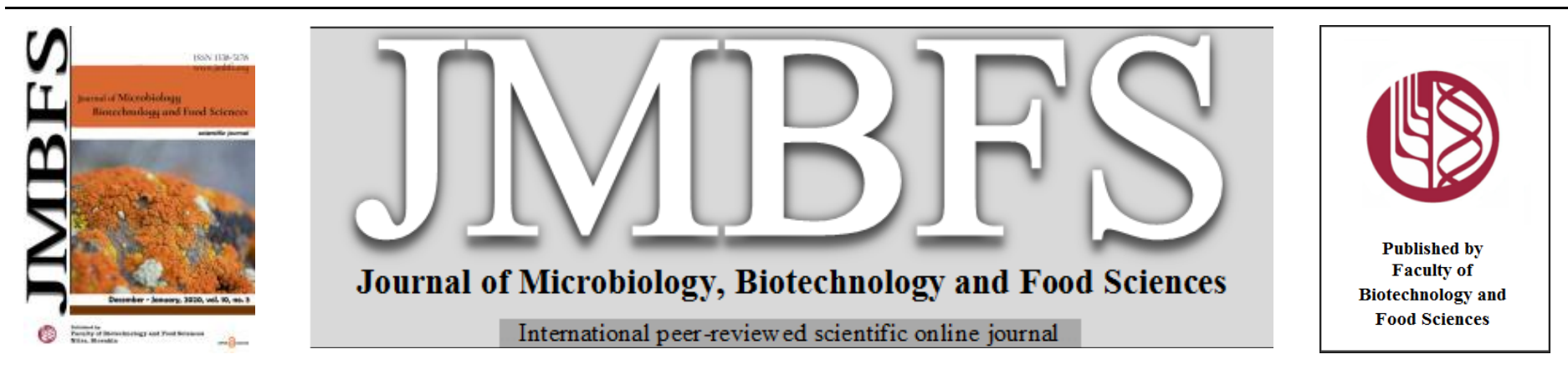

\title{
PROXIMATE AND CHEMICAL PROPERTIES OF SOME UNDERUTILIZED NIGERIAN WILD MUSHROOMS
}

\author{
Mobolaji Adenike Titilawo ${ }^{* 1,2}$, Anthonia Olufunke Oluduro ${ }^{2}$, Olu Odeyemi $^{2}$ \\ Address(es): Mobolaji Adenike Titilawo, $\mathrm{PhD}$ \\ ${ }^{1}$ Department of Microbiology, Osun State University, Oke-Baale, Osogbo, Nigeria. \\ ${ }^{2}$ Department of Microbiology, Obafemi Awolowo University, Ile-Ife, Nigeria.
}

*Corresponding author: mobolaji.adeniyi@uniosun.edu.ng

doi: 10.15414/jmbfs.2020.10.3.390-397

ARTICLE INFO

Received 12.12. 2019

Revised 15. 7. 2020

Accepted 10. 8. 2020

Published 1. 12. 2020

Regular article

OPEN OACCESS

\begin{abstract}
This investigation aims at determining the nutritional value of twenty-three underutilized wild macrofungi from a biodiversity forest in Southwest Nigeria. The mushroom species collected across the ligneous (woody) and terrestrial (soil) habitats were analysed for proximate (moisture, protein, fibre, lipid, ash and carbohydrate), minerals (potassium, sodium, phosphorus, magnesium, calcium, iron and zinc) and vitamins $\mathrm{A}$ and $\mathrm{C}$ content following standard analytical procedures. Interestingly, all the mushrooms had high moisture $(>80.91 \%)$ and those harvested from soil debris in the terrestrial habitat contained significantly high protein content $(26.80-48.68 \%)$ Dietary fibre was in the range of 0.20 and $42.37 \%$; low lipid $(0.12-9.89 \%)$ and ash $(1.25-14.08 \%)$ were also recorded. Furthermore, all the samples contained high carbohydrate except Macrolepiota procera $(2.01 \%)$. Minerals varied across the habitats and ranged as follows: potassium (268.13 - $\left.8972.00 \mathrm{mg} .100 \mathrm{~g}^{-1}\right)$, sodium $\left(89.36-425.92 \mathrm{mg} .100 \mathrm{~g}^{-1}\right)$, phosphorus $\left(0.32-375.51 \mathrm{mg} .100 \mathrm{~g}^{-1}\right)$, magnesium (9.39 - $\left.19.32 \mathrm{mg} .100 \mathrm{~g}^{-1}\right)$ and calcium $\left(7.98-37.82 \mathrm{mg} .100 \mathrm{~g}^{-1}\right)$. Low iron $\left(0.55-1.32 \mathrm{mg} .100 \mathrm{~g}^{-1}\right)$ and zinc $(2.21-4.98$ mg. $100 \mathrm{~g}^{-1}$ ) were obtained. While vitamin A ranged between 0.41 and $1.41 \mathrm{mg} .100 \mathrm{~g}^{-1}$, vitamin $\mathrm{C}$ was from 4.68 to $6.93 \mathrm{mg} .100 \mathrm{~g}^{-1}$. Conclusively, the mushrooms investigated are a good source of nutrients and thus, can be exploited as foods or food supplements.
\end{abstract}

Keywords: wild mushrooms, habitats, nutrient composition, minerals, vitamins, Nigeria

\section{INTRODUCTION}

Mushrooms are important constituents of forest produce and very significant in the human diet (Gbolagade et al., 2006; Jonathan et al., 2013). They are sporebearing fruitbodies of fungi growing on soil or its food substrates, with some existing in natural habitats in a mycorrhizal relationship with trees (Onuoha and Obi-Adumanya, 2010), and are abundant during the rainy season in the tropics (Adeniyi et al., 2018a). Mushrooms were formerly grouped under the Kingdom Plantae that does not photosynthesize, now, classified under divisions Basidiomycota and Agaricomycota of the Fungi Kingdom (Thatoi and Sindevsachan, 2014).

During the growing season of mushrooms in the wild, women, especially in rura communities, practice traditional hunting of edible varieties (Jonathan, 2002; Ayodele et al., 2011) for diverse purposes including nutritional and medicinal (Odebode, 2005; Okhuoya et al., 2010), augmenting family income (Osemwegie and Okhuoya, 2009; Okhuoya et al., 2010; Ayodele et al., 2011) amongst others. Generally, mushrooms are rich in proteins, vitamins and minerals, but low in cholesterol levels (Belewu and Belewu, 2005; Afiukwa $\boldsymbol{e t}$ al., 2015). Factors including the growing site, substrate, and mushroom types, are crucial to their nutrient composition (Nasiri et al., 2012; Okwulehie et al., 2014). They are considered an alternative rich source of meat, fish, vegetables, and fruits and ideal supplements for many low vitamin food materials in human diets (Afiukwa et al., 2013).

Globally, the nourishment potential of the over 14,000 wild mushroom taxon's has long been outshined by the well-known cultivated edible species such as Lentinus edodes, Pleurotus species, and Agaricus bisporus (Wasser, 2002; Shelley and Geoffrey, 2004; Nakalembe et al., 2015). However, in some developing countries of the world including India, Uganda and Kenya, the dietary contents of some wild species are reported with much emphasis on the varieties known to be safe for consumption (Johnsy et al., 2011; Musieba et al., 2013; Kumari and Atri, 2014; Nakalembe et al., 2009; 2015).

In spite of the proliferation of wild mushrooms in the nooks and crannies of Nigeria, there is still a paucity of information on their nutritional values. Few edible varieties in the genera Auricularia, Lentinus, Pleurotus, Schizophyllum Volvoriella, Psathyrella, Russula and the highly-priced Termitomyces are commonly reported (Egwim et al., 2011; Afiukwa et al., 2013; Ayodele and Okhuoya, 2009; Ijioma et al., 2015). This represents only about $5 \%$ of the previously reported wild Nigerian mushroom (Adeniyi et al., 2018a). In the current study, the proximate, minerals and vitamins A and C content of twentythree underutilized wild macrofungi from a biodiversity forest in Southwest Nigeria were determined.

\section{MATERIALS AND METHODS}

Sample collection and presumptive identification

Exactly 10 specimens of 23 wild mushroom species were collected from the biodiversity forest of Environmental Pollution Science and Technology (ENPOST) farm, Ido-Ijesa, Ilesa, Southwest Nigeria located at latitude $4^{\circ} 42^{\prime} 30^{\prime} \mathrm{E}$ to $4^{\circ} 42^{\prime} 45^{\prime \prime} \mathrm{E}$ and longitude $7^{\circ} 36^{\prime} 55^{\prime \prime} \mathrm{N}$ to $7^{\circ} 37^{\prime} 10^{\prime \prime} \mathrm{N}$. After harvest, mushrooms were presumptively identified using standard keys and comparison of the surface morphologies with existing literature (Nwordu et al., 2013; Odeyemi and Adeniyi, 2015). Following probable identification, 3 to 9 different carpophores of each species were cleaned, dried and ground for further analysis.

\section{Edibility test}

Mushrooms with characteristic woody or tough texture and small-sized were classified as inedible. The soft fleshy ones were screened for the presence of toxin following the methods previously described (Feeney et al., 2014; Ohnuki et al., 2016). A droplet of fresh mushroom juice was placed on a piece of old paper print, allowed to dry and $\mathrm{HCl}$ was dropped on it. A blue spot indicated a positive reaction for the presence of a toxin.

\section{Proximate analysis of mushroom samples}

Proximate analysis including moisture, protein, dietary fibre, lipid, ash and carbohydrate of the mushrooms were performed accordingly (AOAC, 2016).

\section{Mineral determination of mushroom samples}

Atomic absorption spectrophotometric (AAS) (Buck Scientific, 210VGP, UK) was employed in the determination of $\mathrm{Mg}, \mathrm{Ca}, \mathrm{Fe}$ and $\mathrm{Zn}$ using oxidizing airacetylene flame at $285.2 \mathrm{~nm}, 422.6 \mathrm{~nm}, 248.3 \mathrm{~nm}$, and $213.3 \mathrm{~nm}$ respectively, 
following the manufacturer's instruction. Determination of sodium (Na) and potassium (K) were done using flame photometry (Jenway, PFP7, UK) following the manufacturer's guide. The spectrophotometry method using Yellow Vanado molybdate was used in the determination of phosphorus in the mushroom samples (AOAC, 2016).

\section{Determination of vitamins $\mathrm{A}$ and $\mathrm{C}$}

The chemicals and reagents used included HPLC-grade. Analytical reagent-grade acetonitrile and methanol (Tedia, USA) and vitamins A and C standards (Sigma, Dorset) were used for the analysis.

\section{Vitamin A}

One gram $(1 \mathrm{~g})$ of pyrogallic acid, $70 \mathrm{ml}$ ethanol and $30 \mathrm{ml}(50 \%) \mathrm{KOH}$ were added to $10 \mathrm{~g}$ mushroom powder, stirred, and refluxed for $40 \mathrm{~min}$ using a water bath $\left(50 \pm 2{ }^{\circ} \mathrm{C}\right)$. Extracts were obtained three times using 50, 30 and $20 \mathrm{ml}$ ether. Double-distilled water was used to neutralize the extract, anhydrous sodium sulphate added to dehydrate it and further concentrated to $5 \mathrm{ml}$ using a water bath $\left(50 \pm 2{ }^{\circ} \mathrm{C}\right)$. Methanol was added to the concentrate to $10 \mathrm{ml}$ mark, filtered using a $0.45 \mu \mathrm{m}$ membrane, and finally subjected to HPLC analysis.

Reversed-phase (RP) HPLC analysis was performed with the Agilent 1100 series HPLC system (Agilent; USA), including a diode array detector. The column was made of stainless steel Agilent Eclipse XDB-C18 column $(5 \mu \mathrm{m}, 4.6 \times 150 \mathrm{~mm})$ and methanol and UV detection was recorded at $325 \mathrm{~nm}$ for vitamin A. Separation was based on isocratic elution and the solvent flow rate was maintained at $1 \mathrm{ml} . \mathrm{min}^{-1}$. Twenty microlitre of mushroom extract was directly injected into the HPLC column. Identification was done by comparing their retention times with those of known standards. All procedures were carried out under subdued light conditions. Standard solutions of vitamin A were prepared from stock stored in the dark at $-20^{\circ} \mathrm{C}$ by serial dilution to concentrations of 0.1 , $1,2,5$, and $10 \mathrm{mg}$ per litre of vitamin A. Twenty microlitre of the standard solution was injected, and peak areas were determined to generate standard curves.

\section{Vitamin C}

Ten grams (10 g) of mushroom powder was mixed with extracting solution prepared by dissolving $15 \mathrm{~g}$ of metaphosphoric acid with $40 \mathrm{ml}$ acetic acid and made up to $500 \mathrm{ml}$ with distilled water. The mixture was filtered through Whatman No. 1 filter paper and samples were extracted in triplicate. Ascorbic acid standard solution was prepared by weighing $100 \mathrm{mg}$ ascorbic acid, dissolved and made up to $100 \mathrm{ml}$ with metaphosphoric acid - acetic solution. The calibration line was converted to a line arrange based on four measured concentration levels. Quantification of ascorbic acid content was performed on an Agilent HPLC system. Chromatographic separation was achieved on an RPHPLC column through the isocratic delivery of a mobile phase (A/B 33/67; A: $0.1 \mathrm{M}$ potassium acetate, $\mathrm{pH}=4.9, \mathrm{~B}$ : acetonitrile: water [50:50]) at a flow rate of $1 \mathrm{ml}$. $\mathrm{min}^{-1}$. UV absorbance was recorded at $254 \mathrm{~nm}$ at room temperature.

\section{Data analysis}

All experiments were carried out in triplicates. Data analyses were performed using SPSS IBM version 23 software. All data were expressed as mean \pm standard deviation. The difference in means was evaluated using ANOVA and Duncan multiple tests employed in case of variance heterogeneity. Values with a probability level of less than 0.05 were considered significant. Nutritional distance and similarity among mushrooms were determined and dendrogram obtained using a complete linkage approach.

\section{RESULTS AND DISCUSSION}

\section{Presumptive identification of mushroom samples}

Mushrooms play significant roles in biogeochemical recycling of elements in the environment, human nutrition and dietetics, and medicines (Odeyemi et al., 2014). In this study, a total of 23 different mushroom samples were collected between April and October, 2018 at ENPOST farm, Ido-Ijesa, Ilesa, Southwest Nigeria, and classified into 17 genera, namely: Amanita, Auricularia, Cantharellus, Ganoderma, Hydnellum, Hydnum, Inonotus, Lentinus, Macrolepiota, Marasmiellus, Oxyporus, Pleurotus, Polyporus, Stereum, Termitomyces, Trametes and Tricholoma. Representative pictures of the mushrooms are shown in figure 1. All the genera had one species each except Auricularia (2), Termitomyces (4), Trametes (2) and Tricholoma (2). These mushrooms had been previously reported (Zoberi, 1973; Alofe, 1985; Gbolagade et al., 2006; Oyetayo, 2009; Okhuoya et al., 2010; Adedayo, 2011; Djelloul and Samraoul, 2011; Johnsy et al., 2011; Nwordu et al., 2013; Adeniyi et al., 2018a;b).

In nature, mushrooms grow on lignocellulose containing substrates (Jonathan $\boldsymbol{e}$ al., 2013; Adeniyi et al., 2018a). While some grow on soil or wood substrates, others exist in mycorrhizal relationship with trees (Onuoha and ObiAdumanya, 2010). In the current study, eight (8) of the mushrooms were from terrestrial habitats whereas the remaining fifteen (15) were of the ligneous origin. This corroborates Adeniyi et al. (2018a) who detected higher mushroom species from the ligneous habitat than the terrestrial. This could probably be attributable to the abundance of lignocellulose substrates, which support the growth of mushrooms on the farm. All the terrestrial mushrooms grew directly on soil debris except Pleurotus tuber-regium, whereas the ligneous mushrooms grew on woody substrates including decaying Cola nitida, Mangifera indica, Bambusa vulgaris leaves, Cordyline australis, and Mangifera indica, decaying Elaeis guineensis and unidentified burnt tree associated with termite nest (Tab 1).

\section{Edibility of the mushroom samples}

All the mushrooms from the terrestrial habitat were fleshy, as against those from the ligneous habitat that were either fleshy, woody or tough. Presumptively, nine of the mushrooms (Ganoderma applanatum, Hydnellum peckii, Hydnum sp. Inonotus radiatus, Marasmiellus candidus, Oxyporus populinus, Stereum hirsutum, Trametes ochracea, and Trametes pubescens) were inedible, twelve (Auricularia auricular-judae, Auricularia polytricha, Cantharellus cibarius, Lentinus subnudus, Macrolepiota procera, Pleurotus tuber-regium, Termitomyces striatus, Termitomyces bulborhizus, Termitomyces robustus, Termitomyces letestui, Tricholoma inocybeoides and Tricholoma ustale) edible, one (Amanita cokeri) poisonous suspect and one (Polyporus sp.) with unknown edibility status (Tab 1).
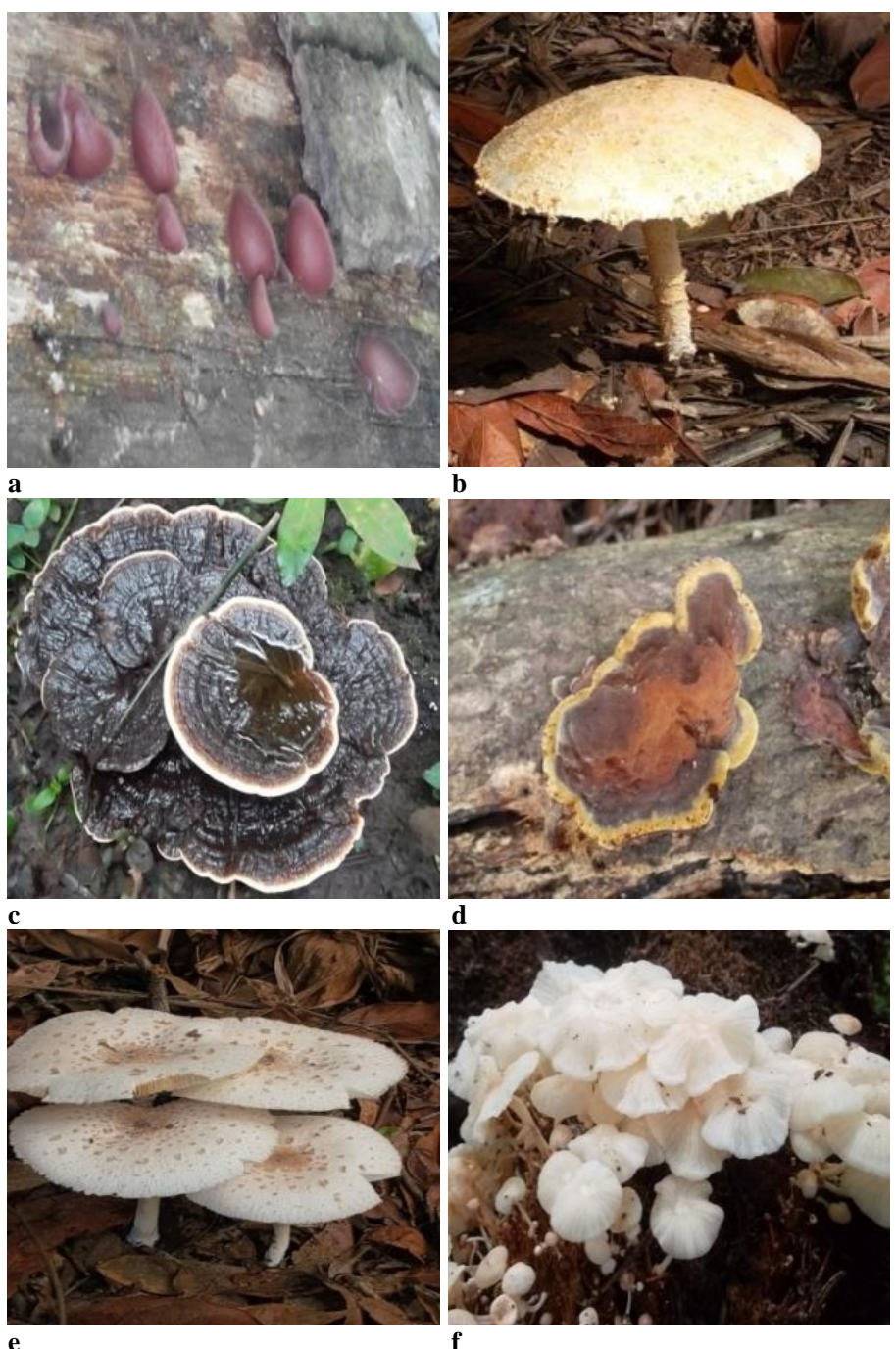

d

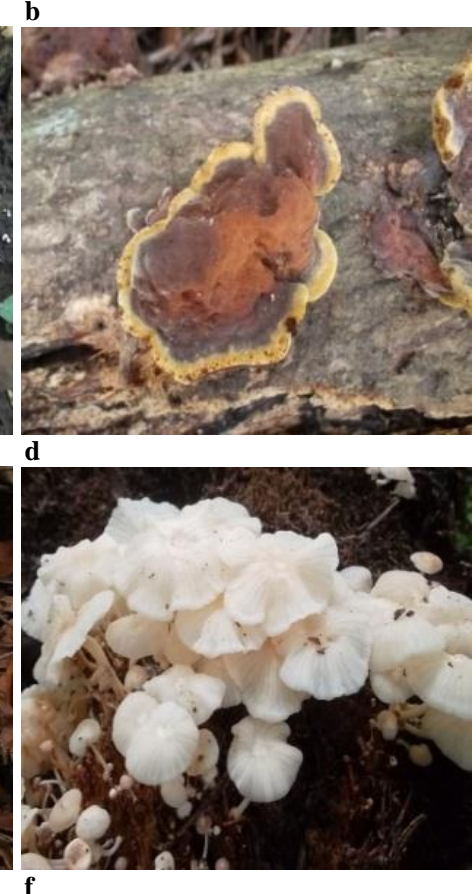
f 


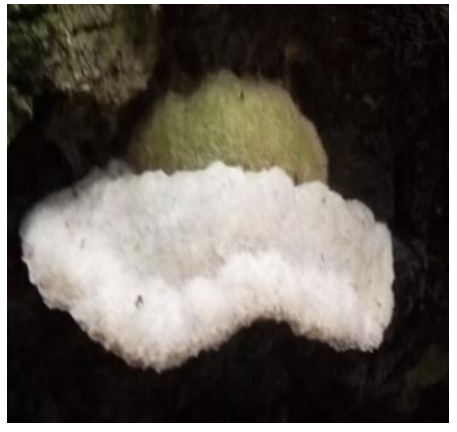

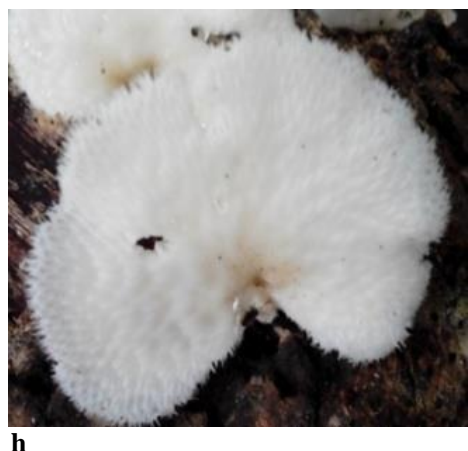

h
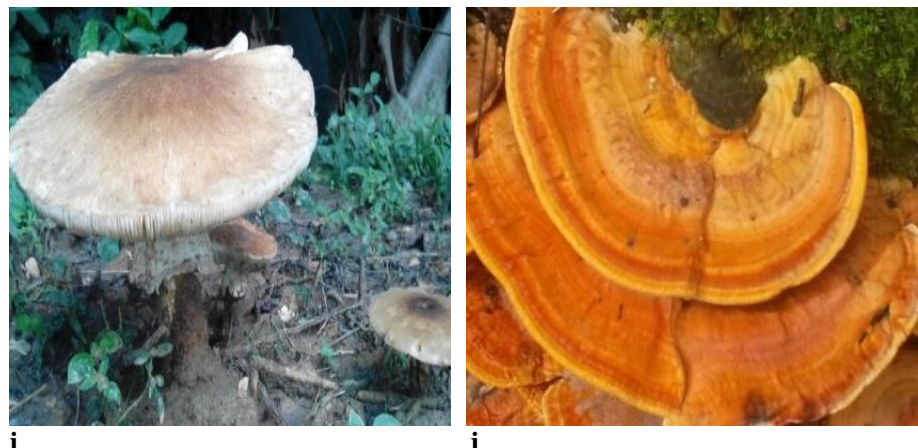

Figure 1 Representative pictures of the mushroom samples

Legend: a - Auricularia polytricha, b - Amanita cokeri, c - Ganoderma applanatum, d - Inonotus radiatus, e - Macrolepiota procera, f - Marasmiellus candidus, g - Oxyporus populinus, h - Polyporus sp., i - Termitomyces bulborhizus, $\mathrm{j}$ - Trametes ochracea

Table 1 Characteristics of mushrooms used in the study

\begin{tabular}{|c|c|c|c|c|c|c|}
\hline $\mathbf{S} / \mathbf{N}$ & Mushroom & Habitat & Substrate & Texture & Edibility & Date of collection \\
\hline 1 & Amanita cokeri & Terrestrial & Soil debris & Fleshy & Poisonous / suspect & $05 / 04 / 2019$ \\
\hline 2 & Auricularia auricular-judae & Ligneous & Dead Cola nitida stem log & Fleshy & Edible & $29 / 05 / 2019$ \\
\hline 3 & Auricularia polytricha & Ligneous & Dead Mangifera indica stem log & Fleshy & Edible & $21 / 06 / 2019$ \\
\hline 4 & Cantharellus cibarius & Ligneous & Decaying Elaeis guineensis & Fleshy & Edible & $17 / 04 / 2019$ \\
\hline 5 & Ganoderma applanatum & Ligneous & Dead Cola nitida stem log & Woody & Inedible & $19 / 05 / 2019$ \\
\hline 6 & Hydnellum peckii & Ligneous & Bambusa vulgaris leaves & Tough & Inedible & $14 / 05 / 2019$ \\
\hline 7 & Hydnum sp. & Ligneous & Cordyline australis tree & Tough & Inedible & $25 / 04 / 2019$ \\
\hline 8 & Inonotus radiatus & Ligneous & Dead Mangifera indica stem log & Woody & Inedible & $16 / 06 / 2019$ \\
\hline 9 & Lentinus subnudus & Ligneous & Dead Mangifera indica stem log & Fleshy & Edible & $23 / 04 / 2019$ \\
\hline 10 & Macrolepiota procera & Terrestrial & Soil debris & Fleshy & Edible & $10 / 05 / 2019$ \\
\hline 11 & Marasmiellus candidus & Ligneous & Decaying Elaeis guineensis & Fleshy & Inedible & $13 / 05 / 2019$ \\
\hline 12 & Oxyporus populinus & Ligneous & Dead Cola nitida stem log & Woody & Inedible & $19 / 05 / 2019$ \\
\hline 13 & Pleurotus tuber-regium & Terrestrial & Sclerotium on soil debris & Fleshy & Edible & 02/05/2019 \\
\hline 14 & Polyporus sp. & Ligneous & Dead Cola nitida stem log & Fleshy & Unknown & 08/06/2019 \\
\hline 15 & Stereum hirsutum & Ligneous & Dead Mangifera indica stem log & Tough & Inedible & $20 / 05 / 2019$ \\
\hline 16 & Termitomyces striatus & Ligneous & $\begin{array}{l}\text { Unidentified burnt tree associated } \\
\text { with termite nest }\end{array}$ & Fleshy & Edible & $12 / 06 / 2019$ \\
\hline 17 & Termitomyces bulborhizus & Terrestrial & Termite mound & Fleshy & Edible & 09/10/2019 \\
\hline 18 & Termitomyces robustus & Terrestrial & Termite mound & Fleshy & Edible & $14 / 10 / 2019$ \\
\hline 19 & Termitomyces letestui & Terrestrial & Termite mound & Fleshy & Edible & $12 / 10 / 2019$ \\
\hline 20 & Trametes ochracea & Ligneous & Dead Cola nitida stump & Woody & Inedible & $25 / 08 / 2019$ \\
\hline 21 & Trametes pubescens & Ligneous & Dead Mangifera indica stem log & Woody & Inedible & $25 / 08 / 2019$ \\
\hline 22 & Tricholoma inocybeoides & Terrestrial & Soil debris & Fleshy & Edible & 07/05/2019 \\
\hline 23 & Tricholoma ustale & Terrestrial & Termite nest & Fleshy & Edible & $25 / 08 / 2019$ \\
\hline
\end{tabular}

Proximate analysis of the mushroom samples

\section{Moisture contents}

Water exists virtually in all foods, and its importance in many physiological processes cannot be over-emphasized. Generally, all the mushrooms analysed in our study contained high moisture ranging from 80.91 to $98.44 \%$ (Tab 2) and agrees with Gbolagade $\boldsymbol{e t}$ al. (2006) and Johnsy $\boldsymbol{e t}$ al. (2011) whose report ranged from 85.4 to $98.5 \%$ and 87.3 to $95.17 \%$ respectively. High moisture contents in mushrooms contribute to low shelf life owing to high water activity that enhances microbial growth and enzyme activity (Gbolagade et al., 2006; Johnsy et al., 2011). Moisture variation may be linked to prevailing environmental growth conditions (Mattila et al., 2001).

\section{Proteins}

Protein contents of mushrooms vary according to the genetic make-up of species and disparity in physicochemical properties of growth substrate (Ragunathan and Swaminathan, 2003; Sanmee et al., 2003; Agrahar-Murugkar and Subbulakshmi, 2005). Overall, mushrooms harvested from soil debris (terrestrial habitat) were higher in protein than those from the ligneous habitat (Tab 2). This may be due to high organic matter in substrates constituting the habitat. Of all the higher fungi investigated, $M$. procera was the richest in protein $(48.68 \pm 0.13 \%)$. This disagrees with Kumari and Atri (2014) who reported $19.95 \pm 1.06 \%$ for the same mushroom. The protein value $(45.50 \pm 0.06 \%)$ obtained for A. cokeri, a poisonous suspect mushroom was higher than the presumed edible Termitomyces and Tricholoma species suggesting it as an attractive and useful species for biotechnological manipulation as a food source. The lowest protein content was detected in Hydnum sp. (11.48 $\pm 0.06 \%)$. Protein obtained for other edible species including A. auricular-judae $(19.60 \pm 0.06 \%)$, A. polytricha $(12.29 \pm$ $0.06 \%)$, L. subnudus (18.74 $\pm 0.12 \%)$ and P. tuber-regium $(19.84 \pm 0.67 \%)$ were higher than the report of Johnsy et al. (2011) but lower than the findings of Gbolagade $\boldsymbol{e t}$ al. (2006). The difference in geographical location and substrates may be responsible for this.

\section{Dietary fibres}

Current trends recommend a drive towards diets that contain a greater amount of plant foods as implicated in preserving and/or improving personal wellbeing (Rodri'guez et al., 2006; Usha and Suguna, 2014). Dietary fibres of the mushrooms studied varied across habitats (Tab 2). With the exception of $T$. ochracea $(0.20 \pm 0.01 \%)$ and $G$. applanatum $(42.37 \pm 0.02 \%)$, the values recorded fell within the ranges reported elsewhere (Breene, 1990; Chye et al. 2008; Egwim et al., 2011; Johnsy et al., 2011; Musieba et al., 2013; Kumari and Atri, 2014). The significantly high dietary fibre in G. applanatum indicates the presence of high leftovers of plant cells resistant to hydrolysis by the alimentary enzymes of man (Capuano, 2017). However, the value obtained in $T$. ochracea is comparable with broccoli $(0.15 \%)$, red radish $(0.19 \%)$, white radish $(0.16 \%)$, sweet yellow pepper $(0.11 \%)$, spring onions $(0.21 \%)$ and tomato $(0.18 \%)$ (Januškevičius et al., 2012). Dietary fibre benefits in preventing of heart diseases, colon cancer and diabetes (Kassegn, 2018).

\section{Lipids}

Lipids provide the major caloric value in foods and excess intake can consequentially lead to coronary heart disease and other health issues (dos 
Passos et al., 2013). Mushrooms are low in lipids dominated by unsaturated fatty acids, contributing less to the energy required in human diet and serving as a means of combating obesity (Wani et al., 2010). Generally, the current investigation ranged between 0.12 and $9.89 \%$ (Tab 2). This tally with the observation of Maftoun et al. (2015). Difference in mushroom species may account for the varied lipid contents observed in the study.

\section{Ash}

Ash contents indicate the presence of mineral contents in any given food sample (Kassegn, 2018). Other than T. pubescens $(0.64 \pm 0.01 \%)$, T. inocybeoides $(1.25$ $\pm 0.01 \%)$ and $T$. ustale $(1.37 \pm 0.01 \%)$, ash contents obtained for others correspond with the outcomes of Gbolagade $\boldsymbol{e t}$ al. (2006) and Colak $\boldsymbol{e t}$ al. (2009) who had 4.7 to $15.5 \%$ and 2.00 to $11.38 \%$ respectively (Tab 2). Previous study reported relatively high ash contents in Termitomyces microcarpus (15.13\%) and Termitomyces clypeatus (16.87\%) (Nakalembe et al., 2015).

\section{Carbohydrates}

Carbohydrates are good sources of energy desirable for breakfast and weaning food formulae (Kassegn, 2018). In mushrooms, carbohydrate content constitutes the bulk of fruiting bodies accounting for 50 to $65 \%$ on a dry weight basis (Wani et al., 2010; Di Aniba et al., 2015). In the present investigation, carbohydrate ranged from 2.01 to $67.73 \%$ with $M$. procera and $T$. pubescens having the lowest and highest values of $2.01 \pm 0.04 \%$ and $67.44 \pm 0.06 \%$ respectively (Tab 2). Our findings on $M$. procera concur with Egwim et al. (2011) who indicated $8 \%$ but opposes Kumari and Atri (2014) who reported 60.82\%. Similarly, Usha and Suguna (2014) reported lower carbohydrate content $(28.5 \%)$ for A. polytricha in their study. In the case of Johnsy et al. (2011), 50.20, 43.4, 47.83 and $33.23 \%$ were documented for P. tuber-regium, P. ostreatus, Lentinus squarrosulus and $A$ auricular-judae respectively.

\begin{tabular}{|c|c|c|c|c|c|c|}
\hline Mushroom & $\begin{array}{l}\text { MC } \\
{[\%]} \\
\end{array}$ & $\begin{array}{c}\mathbf{P} \\
{[\%]}\end{array}$ & $\begin{array}{c}\text { DF } \\
{[\%]}\end{array}$ & $\begin{array}{l}\text { LD } \\
{[\%]}\end{array}$ & $\begin{array}{c}\mathbf{A} \\
{[\%]}\end{array}$ & $\begin{array}{c}\text { CHO } \\
{[\%]} \\
\end{array}$ \\
\hline Amanita cokeri & $95.84 \pm 0.08^{\mathrm{efg}}$ & $45.50 \pm 0.06^{\mathrm{b}}$ & $12.44 \pm 0.01^{\mathrm{h}}$ & $3.81 \pm 0.01^{1}$ & $12.32 \pm 0.01^{\mathrm{c}}$ & $21.50 \pm 0.62^{\mathrm{q}}$ \\
\hline Auricularia auricular-judae & $95.55 \pm 0.30^{\mathrm{fgh}}$ & $19.60 \pm 0.06^{\mathrm{jk}}$ & $2.41 \pm 0.02^{\mathrm{r}}$ & $0.53 \pm 0.03^{r}$ & $4.98 \pm 0.02^{\mathrm{k}}$ & $67.40 \pm 0.04^{\mathrm{a}}$ \\
\hline Auricularia polytricha & $94.92 \pm 0.68^{\mathrm{ij}}$ & $12.29 \pm 0.06^{\mathrm{q}}$ & $4.32 \pm 0.01^{\mathrm{t}}$ & $0.55 \pm 0.01^{\mathrm{r}}$ & $2.27 \pm 0.01^{\mathrm{r}}$ & $67.44 \pm 0.06^{\mathrm{a}}$ \\
\hline Cantharellus cibarius & $95.94 \pm 0.09^{\mathrm{ef}}$ & $31.05 \pm 0.06^{\mathrm{f}}$ & $4.56 \pm 0.01^{\mathrm{s}}$ & $9.30 \pm 0.01^{b}$ & $11.53 \pm 0.03^{\mathrm{e}}$ & $29.94 \pm 0.04^{\circ}$ \\
\hline Ganoderma applanatum & $95.12 \pm 0.28^{\mathrm{hi}}$ & $21.20 \pm 0.12^{\mathrm{i}}$ & $42.37 \pm 0.02^{\mathrm{a}}$ & $6.60 \pm 0.01^{\mathrm{e}}$ & $2.09 \pm 0.01^{\mathrm{s}}$ & $17.64 \pm 0.12^{\mathrm{r}}$ \\
\hline Hydnellum peckii & $94.31 \pm 0.01^{\mathrm{k}}$ & $21.40 \pm 0.00^{\mathrm{i}}$ & $18.55 \pm 0.03^{\mathrm{c}}$ & $1.14 \pm 0.01^{\circ}$ & $4.57 \pm 0.01^{\mathrm{m}}$ & $43.94 \pm 0.01^{\mathrm{i}}$ \\
\hline Hydnum sp. & $91.25 \pm 0.07^{\mathrm{n}}$ & $11.48 \pm 0.06^{\mathrm{r}}$ & $7.34 \pm 0.01^{\circ}$ & $6.09 \pm 0.01^{\mathrm{g}}$ & $14.02 \pm 0.03^{\mathrm{b}}$ & $48.18 \pm 0.08^{g}$ \\
\hline Inonotus radiatus & $80.91 \pm 0.13^{\mathrm{q}}$ & $16.20 \pm 0.06^{\mathrm{m}}$ & $12.41 \pm 0.02^{\mathrm{i}}$ & $0.93 \pm 0.01^{\mathrm{q}}$ & $11.88 \pm 0.01^{\mathrm{d}}$ & $44.96 \pm 0.03^{\mathrm{h}}$ \\
\hline Lentinus subnudus & $95.31 \pm 0.44^{\mathrm{ghi}}$ & $18.74 \pm 0.12^{1}$ & $29.91 \pm 0.01^{\mathrm{b}}$ & $1.00 \pm 0.01^{\mathrm{p}}$ & $14.08 \pm 0.02^{\mathrm{a}}$ & $27.73 \pm 0.12^{\mathrm{p}}$ \\
\hline Macrolepiota procera & $95.59 \pm 0.16^{\text {efgh }}$ & $48.68 \pm 0.13^{\mathrm{a}}$ & $14.35 \pm 0.01^{\mathrm{e}}$ & $8.59 \pm 0.02^{c}$ & $10.83 \pm 0.02^{\mathrm{f}}$ & $2.01 \pm 0.04^{\mathrm{s}}$ \\
\hline Marasmiellus candidus & $94.54 \pm 0.28^{\mathrm{jk}}$ & $31.57 \pm 0.06^{\mathrm{e}}$ & $8.38 \pm 0.01^{\mathrm{m}}$ & $6.48 \pm 0.02^{\mathrm{f}}$ & $7.69 \pm 0.01^{\mathrm{h}}$ & $38.14 \pm 0.05^{1}$ \\
\hline Oxyporus populinus & $88.87 \pm 0.19^{\circ}$ & $19.44 \pm 0.06^{\mathrm{k}}$ & $11.77 \pm 0.01^{\mathrm{k}}$ & $0.12 \pm 0.01^{\mathrm{u}}$ & $4.77 \pm 0.01^{1}$ & $51.90 \pm 0.08^{\mathrm{e}}$ \\
\hline Pleurotus tuber-regium & $95.41 \pm 0.28^{\mathrm{fghi}}$ & $19.84 \pm 0.67^{\mathrm{j}}$ & $6.45 \pm 0.01^{\mathrm{p}}$ & $0.26 \pm 0.01^{\mathrm{t}}$ & $2.62 \pm 0.01^{\circ}$ & $55.91 \pm 0.64^{\mathrm{d}}$ \\
\hline Polyporus sp. & $92.45 \pm 0.06^{\mathrm{m}}$ & $15.30 \pm 0.00^{\mathrm{n}}$ & $13.03 \pm 0.00^{\mathrm{g}}$ & $0.44 \pm 0.01^{\mathrm{s}}$ & $2.34 \pm 0.01^{\mathrm{q}}$ & $56.27 \pm 0.03^{\mathrm{cd}}$ \\
\hline Stereum hirsutum & $83.09 \pm 0.13^{\mathrm{p}}$ & $14.67 \pm 0.00^{\circ}$ & $13.25 \pm 0.01^{\mathrm{f}}$ & $1.97 \pm 0.01^{\mathrm{m}}$ & $2.43 \pm 0.02^{\mathrm{p}}$ & $56.48 \pm 0.03^{\mathrm{c}}$ \\
\hline Termitomyces striatus & $94.91 \pm 0.14^{\mathrm{ij}}$ & $26.53 \pm 0.12^{\mathrm{h}}$ & $12.36 \pm 0.01^{\mathrm{j}}$ & $7.44 \pm 0.01^{\mathrm{d}}$ & $4.76 \pm 0.01^{1}$ & $42.69 \pm 0.43^{j}$ \\
\hline Termitomyces bulborhizus & $98.44 \pm 0.20^{\mathrm{a}}$ & $27.53 \pm 0.06^{\mathrm{g}}$ & $6.25 \pm 0.01^{\mathrm{q}}$ & $4.74 \pm 0.03^{\mathrm{k}}$ & $5.97 \pm 0.01^{\mathrm{j}}$ & $49.00 \pm 0.01^{\mathrm{f}}$ \\
\hline Termitomyces robustus & $97.80 \pm 0.15^{\mathrm{b}}$ & $31.00 \pm 0.06^{\mathrm{f}}$ & $7.36 \pm 0.01^{\circ}$ & $6.50 \pm 0.02^{\mathrm{f}}$ & $4.36 \pm 0.01^{\mathrm{n}}$ & $39.51 \pm 0.08^{\mathrm{k}}$ \\
\hline Termitomyces letestui & $96.95 \pm 0.08^{c}$ & $26.80 \pm 0.06^{\mathrm{h}}$ & $5.46 \pm 0.14^{\mathrm{r}}$ & $5.21 \pm 0.14^{\mathrm{i}}$ & $7.45 \pm 0.01^{\mathrm{i}}$ & $48.80 \pm 0.06^{\mathrm{f}}$ \\
\hline Trametes ochracea & $93.53 \pm 0.20^{1}$ & $16.04 \pm 0.06^{\mathrm{m}}$ & $0.20 \pm 0.01^{\mathrm{u}}$ & $5.43 \pm 0.01^{\mathrm{h}}$ & $9.26 \pm 0.01^{\mathrm{g}}$ & $57.27 \pm 0.06^{\mathrm{b}}$ \\
\hline Trametes pubescens & $94.10 \pm 0.13^{\mathrm{k}}$ & $12.77 \pm 0.06^{\mathrm{p}}$ & $16.61 \pm 0.01^{\mathrm{d}}$ & $1.82 \pm 0.01^{\mathrm{n}}$ & $0.64 \pm 0.01^{\mathrm{v}}$ & $67.73 \pm 0.08^{\mathrm{a}}$ \\
\hline Tricholoma inocybeoides & $96.10 \pm 0.13^{\mathrm{de}}$ & $41.30 \pm 0.06^{\mathrm{c}}$ & $9.21 \pm 0.01^{1}$ & $4.92 \pm 0.01^{\mathrm{j}}$ & $1.25 \pm 0.01^{\mathrm{u}}$ & $31.45 \pm 0.06^{\mathrm{n}}$ \\
\hline Tricholoma ustale & $96.46 \pm 0.20^{\mathrm{cd}}$ & $34.43 \pm 0.12^{\mathrm{d}}$ & $7.53 \pm 0.01^{\mathrm{n}}$ & $9.89 \pm 0.01^{\mathrm{a}}$ & $1.37 \pm 0.01^{\mathrm{t}}$ & $33.48 \pm 0.04^{\mathrm{m}}$ \\
\hline
\end{tabular}

Mean with a different letter in each column are significantly different from each other at $p<0.05$.

Mean values are averages of 3 values.

Legend: MC - Moisture content, P - Protein, DF - Dietary fibre, LD - Lipid, A - Ash, CHO - Carbohydrate.

\section{Mineral and vitamin compositions of mushroom samples}

\section{Potassium}

Potassium controls the water and minerals in the blood and tissues, and significant in the transmission of electrical impulses in the heart (Kowey, 2002) Among all the nutrients analysed, potassium predominates other minerals (Tab 3). This is in line with some studies conducted elsewhere (Akyüz and Kirbağ 2010; Ayodele and Okhuoya, 2009; Okwulehie and Ogoke, 2013; Nakalembe et al., 2015). However, the range of potassium indicated in this study (268.13 $8972.00 \mathrm{mg} .100 \mathrm{~g}^{-1}$ ) was higher than those of Gbolagade et al. (2006) (7.8 $\left.60.1 \mathrm{mg} .100 \mathrm{~g}^{-1}\right)$ and Okwulehie and Ogoke (2013) (112.14 - $164.54 \mathrm{mg} .100 \mathrm{~g}$ $\left.{ }^{1}\right)$.

\section{Sodium}

Sodium is the main electrolyte and major cation outside the cell (Knochel, 1999; Wardlaw and Kessel, 2002). In contrast to some previous studies (Gbolagade $\boldsymbol{e}$ al., 2006; Akyüz and Kirbağ, 2010), the sodium content of mushrooms studied was significantly high (89.36 - $\left.425.92 \mathrm{mg} .100 \mathrm{~g}^{-1}\right)$ (Tab 3). While Gbolagade et al. (2006) documented a range of 0.2 to $6.3 \mathrm{mg} .100 \mathrm{~g}^{-1}$, Akyüz and Kirbağ (2010) had 0.2 to $1.2 \mathrm{mg}$. $100 \mathrm{~g}^{-1}$. Furthermore, the values obtained exceeded the recommendations of the World Health Organisation (WHO) daily sodium intake ( $\leq 2000 \mathrm{mg}$ ) and the UK government (2400 mg per day) (WHO, 2006; Mohan et al., 2009). High dietary sodium has been found implicated in some health consequences including an increase in blood pressure, hypertension, direct vascular and cardiac damage, obesity, stomach cancer, osteoporosis, kidney stones and severity of asthma symptoms (de Wardener and MacGregor, 2002; Mohan et al., 2009).

\section{Phosphorus}

Phosphorus is needed to build strong and healthy bones, sustains norma acid/base balance, supports growth and is involved with the storage and use of energy (dos Passos et al., 2013). In this study, phosphorus was found to vary across habitats and differ significantly $(\mathrm{p}<0.05)$. Its content $(0.32-375.51 \mathrm{mg}$ $100 \mathrm{~g}^{-1}$ ) (Tab 3) was lower than the report of Nakalembe et al. (2015) (10.2 $16.8 \mathrm{mg} .100 \mathrm{~g}^{-1}$ ) but higher in Okwulehie and Ogoke (2013) except for Hydnum sp. (23.62 mg. $100 \mathrm{~g}^{-1}$ ) and Trametes pubescens $\left(0.32 \mathrm{mg} .100 \mathrm{~g}^{-1}\right.$ ) (Tab 3 ). The tolerable upper intake level for phosphorus is $3 \mu \mathrm{g}$ per day for children and 3 to $4 \mu \mathrm{g}$ per day for adults (Food and Nutrition Board, 2016) suggesting that little dose of the mushrooms is needed in daily diet.

\section{Magnesium}

Magnesium ranged from 9.39 to $19.32 \mathrm{mg}$. $100 \mathrm{~g}^{-1}$ ) (Tab 3) and its lowe compared to many common legumes $\left(178-197 \mathrm{mg}\right.$. $\left.100 \mathrm{~g}^{-1}\right)$, whole-grain cereal (121 - 434 mg. $\left.100 \mathrm{~g}^{-1}\right)$ (FAO, 2012), and edible mushrooms (Nakalembe et al., 2015). However, it is higher than Sanmee et al. (2003) and Gbolagade et al. (2006) who observed a range of $0.5-1.6 \mathrm{mg} .100 \mathrm{~g}^{-1}$ and $0.4-6.7 \mathrm{mg} .100 \mathrm{~g}^{-1}$ respectively. Magnesium is crucial in control of muscle contraction, blood pressure, insulin metabolism, and synthesis of DNA, RNA and proteins (Grober et al., 2015). It plays an important role in nerve transmission and neuromuscular conduction and protection against excessive excitation that can lead to excitotoxicity (Kirkland et al., 2018). 


\section{Calcium}

Calcium is one of the foremost microminerals in the bone and teeth of human beings and animals and reduces the chance of having cardiac disorder or any heart-related challenge (Titilawo et al., 2018). The obtained values (7.98 - 37.82 mg. $100 \mathrm{~g}^{-1}$ ) (Tab 3) were comparable to many common kinds of cereals (12 - 51 mg. $\left.100 \mathrm{~g}^{-1}\right)$, starchy food $\left(11-43 \mathrm{mg} .100 \mathrm{~g}^{-1}\right)$, meat and poultry products $(4$ 69 mg. $100 \mathrm{~g}^{-1}$ ) (FAO, 2012). However, Chye et al. (2008) obtained a range (77 $144.7 \mathrm{mg} .100 \mathrm{~g}^{-1}$ ) higher than ours. Consumption of a very high concentration of calcium may adversely affect the absorption of the essential elements (Nova Scotia Environment, 2005), nonetheless, its paucity could result in osteoporosis and osteomalacia. Hypertension has also been linked to low calcium in the body (Kožíšek, 2003; Titilawo et al., 2018).

\section{Iron}

Iron is required for the synthesis of haemoglobin in red blood corpuscles and also aids growth and metabolic processes in humans and animals (Kumar and Puri, 2012, Edward et al., 2013; Vetrimurugan et al., 2017; Titilawo et al., 2018). In this work, the iron content $\left(0.55-1.30 \mathrm{mg}\right.$. $\left.100 \mathrm{~g}^{-1}\right)$ (Tab 3) was within the published data for cabbage $\left(0.6 \mathrm{mg} .100 \mathrm{~g}^{-1}\right)$ and meat $\left(1.6 \mathrm{mg} .100 \mathrm{~g}^{-1}\right)$ (Eyabi, 2001). It was however higher than those observed in previous studies (Gbolagade et al., 2006; Ayodele and Okhuoya, 2009), and lower when compared with the findings of Colak et al. (2009), Patil et al. (2010) and Kumari and Atri (2014). Largely, a low quantity of iron was observed in the mushrooms and fell below the recommended nutritional limit $(18 \mathrm{mg})$ for iron, (Food and Nutrition Board, 2016). Thus, the mushrooms are not good sources of dietary iron.

\section{Zinc}

Zinc is a major micronutrient for living organisms. It is present almost in all foods and water as a salt of organic complexes (Swaminathan et al., 2011; Salano, 2013). Generally, the mushrooms in the current study are low in zinc and fell below the $15 \mathrm{mg}$ recommended dietary intake (Food and Nutrition Board, 2016). The range obtained was between 2.21 and $4.98 \mathrm{mg} .100 \mathrm{~g}^{-1}$ (Tab 3). This is lower than the results of previous studies (Gbolagade et al., 2006; Nakalembe et al., 2015) but higher than the report of Okwulehie and Ogoke (2013). When zinc is lacking in the diet, it may lead to a reduction in fertility, forfeiture of taste stunted growth and hypogonadism. Low levels of zinc can as well weaken the body's immunity (Edward et al., 2013; Titilawo et al., 2018).

\section{Vitamin A}

Mushrooms are non-animal sources of vitamin, contributing a very small percentage in human diet and crucial in disease prevention and lengthening of life span (Olaniyi, 2000). The outcome of our work revealed that all the wild mushrooms analysed contained vitamin A (Tab 3). This is contrary to Afiukwa $\boldsymbol{e}$ al. (2013) who detected vitamin A only in Agaricus bisporus among other varieties and with a value higher (38.36 mg. $\left.100 \mathrm{~g}^{-1}\right)$ than what was observed in our case (0.14 - $1.41 \mathrm{mg}$. $\left.100 \mathrm{~g}^{-1}\right)$. Likewise, Musieba et al. (2013) investigated vitamin A in $P$. citrinopileatus and reported a low value $<10 \mu \mathrm{g} / 100 \mathrm{~g}$. Our findings agree with vitamin A level reported for some animal and plant materials including butter $\left(0.59 \mathrm{mg} .100 \mathrm{~g}^{-1}\right)$, cheese $\left(0.39 \mathrm{mg} .100 \mathrm{~g} \mathrm{~g}^{-1}\right)$, egg $(0.28 \mathrm{mg} .100$ $\left.\mathrm{g}^{-1}\right)$, milk (0.04 mg. $\left.100 \mathrm{~g}^{-1}\right)$ and salmon (0.041 mg. $\left.100 \mathrm{~g}^{-1}\right)$ (Souci et al., 2000) Vitamin A role has been established to include apt sight, reproduction, growth and development, cellular differentiation and immune function (Bowman, 2001).

\section{Vitamin C}

The range of vitamin $\mathrm{C}$ obtained in this work was from 5.22 to $6.93 \mathrm{mg} .100 \mathrm{~g}^{-1}$. While the highest vitamin C content was found in Pleurotus tuber-regium, the lowest was detected in T. pubescens (Tab. 3). The values indicated that the mushrooms are considered good sources of ascorbic acid. Earlier studies by Sapers et al. (1999), Mattila et al. (2001) and Mattila et al. (2000) reported vitamin $\mathrm{C}$ content of up to $7 \mathrm{mg}$. $100 \mathrm{~g}^{-1}$. Also, Muthangya et al. (2014) observed 5.07 to $5.29 \mathrm{mg}$. $100 \mathrm{~g} \mathrm{~g}^{-1}$ in edible sections of mushrooms whereas Musieba et al. (2013) recorded a low value of $<1 \mu \mathrm{g} .100 \mathrm{~g}^{-1}$ in Pleurotus citrinopileatus. Ascorbic acids are major antioxidants with known health benefits (Rao and Agarwal, 2000). It empowers the body against viral and bacterial attack and also vital in wound healing (Hemilä, 2017). It is vital for the production of collagen, a key structural constituent of tendons, bones, teeth, blood vessels and muscles. Vitamin $\mathrm{C}$ enhances iron absorption and regenerates other antioxidants including vitamin E (Brody, 1994). On the contrary, deficiency in vitamin $\mathrm{C}$ causes bruising, haemorrhage, dry skin and depression (Olson, 1999). The vitamin is reported to directly interact with radicals in plasma, averting impairment to red cell membranes (Jayakumar et al., 2009).

Table 3 Mineral and vitamin composition of the selected mushroom samples (dry weight basis) (mg. $\left.100 \mathrm{~g}^{-1}\right)$

\begin{tabular}{|c|c|c|c|c|c|c|c|c|c|}
\hline Mushroom & Sodium & Potassium & Magnesium & Calcium & Iron & Zinc & Phosphorus & Vitamin A & Vitamin C \\
\hline Amanita cokeri & $280.37 \pm 0.01^{\mathrm{f}}$ & $8972.00 \pm 0.05^{\mathrm{a}}$ & $12.68 \pm 0.01^{\mathrm{n}}$ & $28.04 \pm 0.01^{\mathrm{e}}$ & $1.05 \pm 0.01^{\mathrm{f}}$ & $2.78 \pm 0.01^{1}$ & $127.56 \pm 0.01^{1}$ & $1.14 \pm 0.01^{\mathrm{ef}}$ & $5.48 \pm 0.02^{\text {cd }}$ \\
\hline Auricularia auricular-judae & $131.57 \pm 0.02^{\mathrm{s}}$ & $2473.68 \pm 0.01^{\mathrm{k}}$ & $15.36 \pm 0.01^{1}$ & $8.76 \pm 0.01^{\mathrm{t}}$ & $1.22 \pm 0.01^{\mathrm{bc}}$ & $2.33 \pm 0.01^{\mathrm{n}}$ & $159.55 \pm 0.02^{\mathrm{i}}$ & $1.34 \pm 0.01^{\mathrm{b}}$ & $6.25 \pm 0.01^{\mathrm{b}}$ \\
\hline Auricularia polytricha & $231.56 \pm 0.01^{\mathrm{h}}$ & $1260.72 \pm 0.01^{\circ}$ & $18.56 \pm 0.01^{\mathrm{d}}$ & $17.14 \pm 0.01^{\mathrm{j}}$ & $1.01 \pm 0.01^{\mathrm{g}}$ & $2.32 \pm 0.01^{\mathrm{n}}$ & $93.25 \pm 0.01^{\mathrm{m}}$ & $1.23 \pm 0.01^{\mathrm{c}}$ & $5.34 \pm 0.01^{\mathrm{cd}}$ \\
\hline Cantharellus cibarius & $425.15 \pm 0.25^{\mathrm{b}}$ & $5954.62 \pm 0.01^{\mathrm{c}}$ & $15.36 \pm 0.01^{1}$ & $37.82 \pm 0.01^{\mathrm{a}}$ & $1.24 \pm 0.01^{\mathrm{b}}$ & $3.87 \pm 0.02^{\mathrm{b}}$ & $208.35 \pm 0.01^{\mathrm{g}}$ & $1.12 \pm 0.01^{\mathrm{fg}}$ & $6.43 \pm 0.02^{\mathrm{b}}$ \\
\hline Ganoderma applanatum & $152.43 \pm 0.02^{\mathrm{q}}$ & $670.73 \pm 0.00^{\mathrm{u}}$ & $17.69 \pm 0.01^{\mathrm{e}}$ & $10.17 \pm 0.01^{1}$ & $1.30 \pm 0.01^{\mathrm{a}}$ & $3.25 \pm 0.01^{\mathrm{j}}$ & $75.74 \pm 0.02^{\mathrm{r}}$ & $1.22 \pm 0.01^{\mathrm{cd}}$ & $5.44 \pm 0.01^{\mathrm{cd}}$ \\
\hline Hydnellum peckii & $196.25 \pm 0.02^{\mathrm{k}}$ & $1570.10 \pm 0.01^{\mathrm{m}}$ & $10.36 \pm 0.01^{\mathrm{p}}$ & $18.67 \pm 0.02^{\mathrm{h}}$ & $1.30 \pm 0.01^{\mathrm{a}}$ & $3.49 \pm 0.01^{\mathrm{f}}$ & $90.60 \pm 0.01^{\mathrm{n}}$ & $1.23 \pm 0.01^{\mathrm{c}}$ & $6.32 \pm 0.01^{\mathrm{b}}$ \\
\hline Hydnum sp. & $174.43 \pm 0.01^{\mathrm{m}}$ & $406.97 \pm 0.01^{v}$ & $19.32 \pm 0.01^{\mathrm{a}}$ & $29.08 \pm 0.01^{\mathrm{d}}$ & $1.10 \pm 0.02^{\mathrm{e}}$ & $2.21 \pm 0.01^{\circ}$ & $23.62 \pm 0.01^{\mathrm{v}}$ & $1.41 \pm 0.01^{\mathrm{a}}$ & $5.38 \pm 0.01^{\mathrm{cd}}$ \\
\hline Inonotus radiatus & $247.26 \pm 0.01^{\mathrm{g}}$ & $1236.28 \pm 0.02^{\mathrm{P}}$ & $17.67 \pm 0.01^{\mathrm{e}}$ & $36.65 \pm 0.02^{\mathrm{b}}$ & $1.32 \pm 0.01^{\mathrm{a}}$ & $2.54 \pm 0.01^{\mathrm{m}}$ & $80.99 \pm 0.01^{\mathrm{p}}$ & $1.11 \pm 0.01^{\mathrm{fg}}$ & $6.22 \pm 0.01^{\mathrm{b}}$ \\
\hline Lentinus subnudus & $113.11 \pm 0.01^{\mathrm{u}}$ & $1724.78 \pm 0.01^{1}$ & $16.32 \pm 0.02^{\mathrm{h}}$ & $9.32 \pm 0.11^{\mathrm{q}}$ & $0.64 \pm 0.01^{\mathrm{k}}$ & $3.13 \pm 0.01^{\mathrm{k}}$ & $154.83 \pm 0.01^{\mathrm{j}}$ & $1.36 \pm 0.01^{\mathrm{b}}$ & $5.56 \pm 0.04^{\mathrm{c}}$ \\
\hline Macrolepiota procera & $166.35 \pm 0.01^{\circ}$ & $3632.14 \pm 0.04^{\mathrm{h}}$ & $15.84 \pm 0.01^{\mathrm{j}}$ & $9.24 \pm 0.02^{\mathrm{r}}$ & $0.74 \pm 0.02^{\mathrm{i}}$ & $3.25 \pm 0.13^{\mathrm{j}}$ & $70.07 \pm 0.01^{\mathrm{u}}$ & $1.04 \pm 0.01^{\mathrm{i}}$ & $6.32 \pm 0.01^{\mathrm{b}}$ \\
\hline Marasmiellus candidus & $329.97 \pm 0.05^{\mathrm{c}}$ & $4241.96 \pm 0.01^{\mathrm{f}}$ & $18.92 \pm 0.01^{\mathrm{b}}$ & $31.43 \pm 0.01^{\mathrm{c}}$ & $1.24 \pm 0.01^{\mathrm{b}}$ & $3.44 \pm 0.01^{\mathrm{g}}$ & $375.51 \pm 0.37^{\mathrm{a}}$ & $1.32 \pm 0.01^{\mathrm{b}}$ & $6.39 \pm 0.02^{\mathrm{b}}$ \\
\hline Oxyporus populinus & $199.44 \pm 0.01^{\mathrm{i}}$ & $1453.00 \pm 0.01^{\mathrm{n}}$ & $17.67 \pm 0.01^{\mathrm{e}}$ & $9.51 \pm 0.01^{\circ}$ & $0.82 \pm 0.01^{\mathrm{h}}$ & $3.63 \pm 0.01^{\mathrm{d}}$ & $193.94 \pm 0.00^{\mathrm{h}}$ & $1.05 \pm 0.07^{\mathrm{hi}}$ & $5.39 \pm 0.02^{\mathrm{cd}}$ \\
\hline Pleurotus tuber-regium & $115.95 \pm 0.01^{\mathrm{t}}$ & $927.55 \pm 0.01^{\mathrm{t}}$ & $16.29 \pm 0.01^{\mathrm{h}}$ & $19.31 \pm 0.01^{\mathrm{g}}$ & $0.68 \pm 0.01^{\mathrm{j}}$ & $3.44 \pm 0.01^{\mathrm{g}}$ & $80.29 \pm 0.01^{q}$ & $1.09 \pm 0.01^{\mathrm{gh}}$ & $6.93 \pm 0.54^{\mathrm{a}}$ \\
\hline Polyporus sp. & $158.03 \pm 0.01^{\mathrm{p}}$ & $1106.22 \pm 0.02^{\mathrm{r}}$ & $10.32 \pm 0.01^{\mathrm{q}}$ & $17.56 \pm 0.01^{\mathrm{i}}$ & $1.30 \pm 0.01^{\mathrm{a}}$ & $3.55 \pm 0.01^{\mathrm{e}}$ & $74.12 \pm 0.01^{\mathrm{s}}$ & $1.02 \pm 0.01^{\mathrm{i}}$ & $5.29 \pm 0.02^{\mathrm{cd}}$ \\
\hline Stereum hirsutum & $93.01 \pm 0.01^{\mathrm{v}}$ & $953.49 \pm 0.00^{\mathrm{s}}$ & $9.39 \pm 0.02^{\mathrm{r}}$ & $15.52 \pm 0.02^{\mathrm{k}}$ & $1.13 \pm 0.02^{\mathrm{d}}$ & $3.34 \pm 0.01^{\mathrm{i}}$ & $73.63 \pm 0.01^{\mathrm{t}}$ & $1.18 \pm 0.04^{\mathrm{de}}$ & $6.22 \pm 0.01^{\mathrm{b}}$ \\
\hline Termitomyces striatus & $195.34 \pm 0.01^{1}$ & $5860.46 \pm 0.01^{\mathrm{d}}$ & $16.49 \pm 0.02^{\mathrm{g}}$ & $9.32 \pm 0.02^{\mathrm{q}}$ & $0.69 \pm 0.01^{\mathrm{j}}$ & $3.78 \pm 0.01^{\mathrm{c}}$ & $371.89 \pm 0.01^{\mathrm{b}}$ & $1.12 \pm 0.01^{\mathrm{fg}}$ & $6.29 \pm 0.02^{\mathrm{b}}$ \\
\hline Termitomyces bulborhizus & $167.07 \pm 0.01^{\mathrm{n}}$ & $5250.60 \pm 0.01^{\mathrm{e}}$ & $15.70 \pm 0.01^{\mathrm{k}}$ & $7.98 \pm 0.02^{\mathrm{v}}$ & $0.55 \pm 0.01^{1}$ & $4.98 \pm 0.01^{\mathrm{a}}$ & $222.55 \pm 0.01^{\mathrm{e}}$ & $1.23 \pm 0.01^{\mathrm{c}}$ & $6.36 \pm 0.04^{\mathrm{b}}$ \\
\hline Termitomyces robustus & $198.01 \pm 0.01^{\mathrm{j}}$ & $7673.26 \pm 0.01^{\mathrm{b}}$ & $15.29 \pm 0.02^{\mathrm{m}}$ & $8.24 \pm 0.02^{\mathrm{u}}$ & $1.09 \pm 0.01^{\mathrm{e}}$ & $3.37 \pm 0.01^{\mathrm{i}}$ & $217.15 \pm 0.01^{\mathrm{f}}$ & $1.23 \pm 0.01^{\mathrm{c}}$ & $5.49 \pm 0.01^{\mathrm{c}}$ \\
\hline Termitomyces letestui & $310.43 \pm 0.01^{\mathrm{d}}$ & $3668.87 \pm 0.01^{\mathrm{g}}$ & $18.78 \pm 0.01^{\mathrm{c}}$ & $9.42 \pm 0.01^{\mathrm{f}}$ & $1.19 \pm 0.01^{\mathrm{c}}$ & $3.40 \pm 0.01^{\mathrm{h}}$ & $271.50 \pm 0.01^{\mathrm{c}}$ & $1.14 \pm 0.01^{\mathrm{ef}}$ & $6.43 \pm 0.01^{\mathrm{b}}$ \\
\hline Trametes ochracea & $138.13 \pm 0.01^{\mathrm{r}}$ & $1160.24 \pm 0.02^{\mathrm{q}}$ & $11.66 \pm 0.01^{\circ}$ & $27.63 \pm 0.01^{\mathrm{f}}$ & $1.02 \pm 0.01^{\mathrm{g}}$ & $3.53 \pm 0.01^{\mathrm{e}}$ & $86.64 \pm 0.01^{\circ}$ & $0.14 \pm 0.01^{\mathrm{j}}$ & $5.22 \pm 0.01^{\mathrm{cd}}$ \\
\hline Trametes pubescens & $89.36 \pm 0.01^{\mathrm{w}}$ & $268.13 \pm 0.01^{\mathrm{w}}$ & $16.26 \pm 0.02^{\mathrm{i}}$ & $9.94 \pm 0.01^{\mathrm{m}}$ & $1.01 \pm 0.01^{\mathrm{g}}$ & $2.55 \pm 0.01^{\mathrm{m}}$ & $0.32 \pm 0.01^{\mathrm{w}}$ & $1.33 \pm 0.01^{\mathrm{b}}$ & $4.68 \pm 0.01^{\mathrm{e}}$ \\
\hline Tricholoma inocybeoides & $425.92 \pm 0.01^{\mathrm{a}}$ & $2608.70 \pm 0.00^{\mathrm{j}}$ & $15.32 \pm 0.01^{\mathrm{m}}$ & $8.84 \pm 0.05^{\mathrm{s}}$ & $1.21 \pm 0.01^{\mathrm{bc}}$ & $3.36 \pm 0.01^{\mathrm{i}}$ & $146.71 \pm 0.01^{\mathrm{k}}$ & $1.19 \pm 0.01^{\mathrm{cd}}$ & $6.29 \pm 0.01^{\mathrm{b}}$ \\
\hline Tricholoma ustale & $292.96 \pm 0.01^{\mathrm{e}}$ & $3281.11 \pm 0.21^{\mathrm{i}}$ & $16.67 \pm 0.02^{f}$ & $9.77 \pm 0.01^{\mathrm{n}}$ & $1.14 \pm 0.00^{\mathrm{d}}$ & $3.39 \pm 0.01^{\mathrm{h}}$ & $223.34 \pm 0.01^{\mathrm{d}}$ & $1.12 \pm 0.01^{\mathrm{fg}}$ & $5.48 \pm 0.01^{\mathrm{cd}}$ \\
\hline
\end{tabular}

Mean with a different letter in each column are significantly different from each other at $\mathrm{p}<0.05$.

Mean values are averages of 3 values.

\section{Nutritive hierarchical cluster analysis of the mushrooms}

Mushrooms fruitbodies are characterized by assimilated mineral constituents whose level depends on, amongst other species, age of mushroom, the diameter of pileus and substratum (Dermirdaş, 2001; Falandysy et al., 2001; Mattila et al., 2001). The nutrition hierarchy cluster shows that there is dietary relatedness among the mushroom species irrespective of their habitat, texture or edibility (figure 2). For instance, the fleshy, edible $P$. tuber-regium and T. inocybeoides in the terrestrial habitat closely associated with woody/tough, inedible $G$. applanatum and $S$. hirsutum in the ligneous habitat respectively. Likewise, the fleshy and edible $T$. striatus and C. cibarius in the ligneous habitat closely related to fleshy, edible T. bulborhizus (terrestrial habitat); and the fleshy, inedible $M$. candidus in the ligneous habitat found clustered with fleshy, edible $M$. procera, T. ustale and T. letestui in the terrestrial habitat (figure 2). Also, the nature of the 
nutrient-rich organic substrate on which $M$. candidus, $C$. cibarius, and $T$. striatus grew may be responsible for dietary relatedness with mushrooms from terrestria habitat. Likewise, the presence of sclerotium in P. tuber-regium and decaying debris where Tricholoma inocybeoides were harvested may be the reason their nutrient content is comparable with mushrooms from the ligneous habitat.

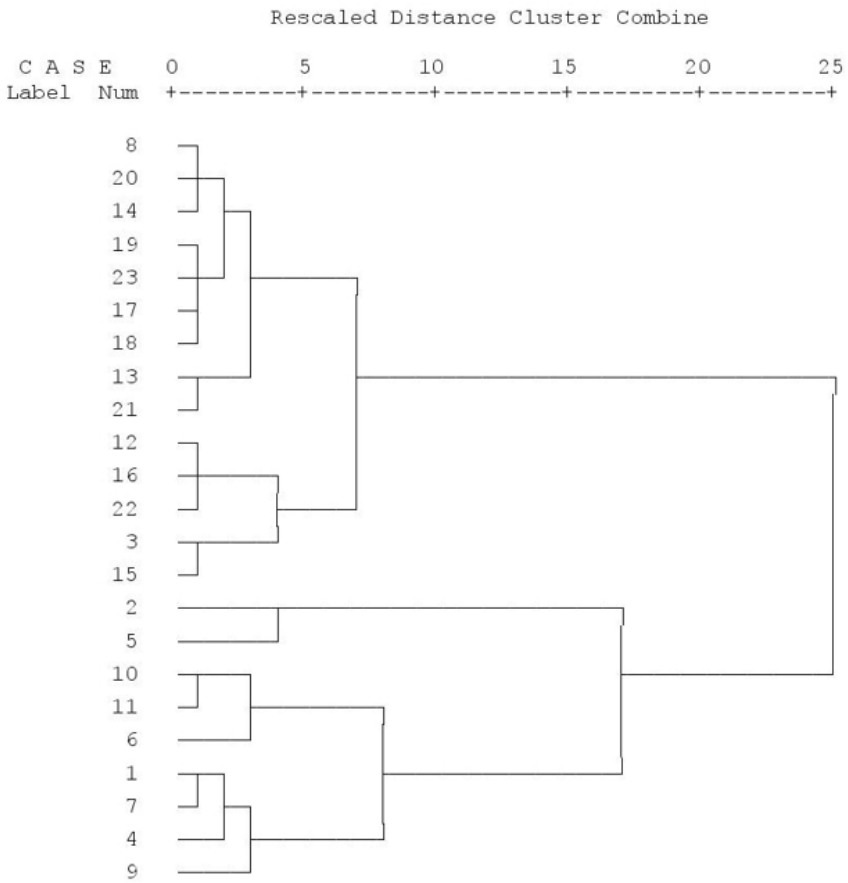

Figure 2 Dendrogram of the nutritive value of the selected mushroom samples Legend: 1 - Macrolepiota procera, 2 - Amanita cokeri, 3 - Tricholoma inocybeoides, 4 Tricholoma ustale, 5 - Termitomyces robustus, 6 - Termitomyces bulborhizus, 7 Termitomyces letestui, 8 - Pleurotus tuber-regium, 9-Marasmiellus candidus, 10 Cantharellus cibarius, 11 - Termitomyces striatus, 12 - Hydnellum peckii, 13 - Hydnum sp. 14 - Ganoderma applanatum, 15 - Auricularia auricular-judae, 16 - Oxyporus populinus, 17 - Trametes ochracea, 18 - Polyporus sp., 19 - Inonotus radiatus; 20 - Stereum hirsutum, 21 Trametes pubescens, 22 - Lentinus subnudus, 23 - Auricularia polytricha

\section{CONCLUSION}

The nutritional composition of twenty-three underutilized Nigerian wild mushrooms was studied. While eight of the mushrooms were from the terrestrial habitat, fifteen were of the ligneous source. Interestingly, all the mushroom species are rich in moisture, protein, dietary fibre, ash, carbohydrate and minerals including sodium, potassium, calcium, magnesium, zinc, and phosphorus, and vitamins $\mathrm{A}$ and $\mathrm{C}$, but low in lipid and iron, an indication that they are highly nutritious; although other sources of sodium must be checked when consuming these mushrooms. Similarly, the nutritive hierarchical cluster analysis shows that the dietary composition of all the mushrooms is related irrespective of their habitat, texture or edibility. Thus, they are potential foods and food supplements and stand to meet the diverse human dietary needs if objectively exploited Further study is however encouraged to ascertain the safety of these mushrooms for consumption.

Conflicts of interest: The authors declare no conflict of interest.

Author contributions: M.A.T and O.O. designed the experiment, M.A.T performed the experiment and drafted the manuscript, M.A.T. and A.O.O. analysed the data, A.O.O. and M.A.T. supervised the study. All authors read and approved the final manuscript

Acknowledgement: This research did not receive any specific grant from funding agencies in the public, commercial or not-for-profit sectors. However the authors appreciate the management of ENPOST farm, Ido-Ijesa, Ilesa, Nigeria for permission to collect mushroom samples. Special thanks goes to Dr. O.Y. Titilawo for proof-reading the manuscript.

\section{REFERENCES}

Adedayo, M.R. (2011). Proximate analysis on four edible mushrooms. Journal of Applied Science and Environmental Management, 15(1), 9-11. https://doi.org/10.4314/jasem.v15i1.65666

Adeniyi, M.A. \& Odeyemi, O. (2012). Comparative cultivation of mushroom (Pleurotus florida) on corncob, wood shred and old newspaper. Proceedings of the $25^{\text {th }}$ Annual Conference of the Biotechnology Society of Nigeria 146-150.
Adeniyi, M.A., Odeyemi, Y. \& Odeyemi, O. (2018a). Ecology, diversity and seasonal distribution of wild mushrooms in a Nigerian tropical forest reserve. Biodiversitas 19(1), 285-295. https://doi.org/10.13057/biodiv/d190139

Adeniyi, M.A., Titilawo, Y., Oluduro, A.O., Odeyemi, O., Nakin, M. \& Okoh, A.I. (2018b). Molecular identification of some wild Nigerian mushrooms using internal transcribed spacer: polymerase chain reaction. AMB Express 8, 148 https://doi.org/10.1186/s13568-018-0661-9

Afiukwa, C. A., Ebem, E. C. \& Igwe, D. O. (2015). Characterization of proximate and amino acid composition of edible wild mushroom species in Abakaliki, Nigeria. America Association for Science and Technology 1(2), 20-25. Afiukwa, C.A., Ugwu, O.P.C., Okoli, S.O., Idenyi, J.N. \& Ossai, E.C. (2013) Contents of some vitamins in five edible mushroom varieties consumed in Abakaliki metropolis, Nigeria. Research Journal of Pharmaceutical, Biological and Chemical Sciences 4(2), 805-812.

Agrahar-Murugkar, D. \& Subbulakshmi, G. (2005). Nutritional value of edible wild mushrooms collected from the Khasi hills of Meghalaya. Food Chemistry 89, 599-603. https://doi.org/10.1016/j.foodchem.2004.03.042

Akyüz, M. \& Kirbağ, S. (2010). Nutritive value of wild edible and cultured mushrooms. Turkish Journal of Biology 34, 97-102. https://doi.org/10.3906/biy0805-17

Alofe, F.V. (1985). The general characteristics and cultivation of some Nigerian mushrooms. Ph.D. Thesis, Obafemi Awolowo University, Ile-Ife, Nigeria.

AOAC (2016). Official methods of analysis of the association of official analytical chemists. $20^{\text {th }}$ ed., Washington, DC.

Ayodele, S. M., Akpaja, E. O. \& Adamu, Y. (2011). Some edible medicinal mushrooms of Igala Land in Nigeria, their socio-cultural and ethnomycological uses. International Journal of Science and Nature 2(3), 473-476.

Ayodele, S.M. \& Okhuoya, J.A. (2009). Nutritional and phytochemical evaluation of cultivated Psathyrella atroumbonata Pegler, a Nigerian edible mushroom. South African Journal of Science 105, 158-160. https://doi.org/10.4102/sajs.v105i3/4.72

Belewu, M. A. \& Belewu, K. Y. (2005). Cultivation of mushroom (Volvariella volvacea) on banana leaves. African Journal of Biotechnology 4(12), 1401-1403. Beluhan, S. \& Ranogajec, A. (2011). Chemical composition and nonvolatile components of Croatian wild edible mushrooms. Food Chemistry 124, 10761082. https://doi.org/10.1016/j.foodchem.2010.07.081

Bowman, B.A. \& Russell, R.B. (2001). Present knowledge in nutrition. Washington, DC: International Life Science Institute, Press.

Breene, W.M. (1990). Nutritional and medicinal value of specialty mushrooms Journal of Food Product 53(10), 883-894.

Brody, T. (1994). Nutritional biochemistry. San Diego, CA: Academic Press. Capuano, E. (2017). The behavior of dietary fiber in the gastrointestinal tract determines its physiological effect. Critical Reviews in Food Science and Nutrition 57(16), 3543-3564. https://doi.org/10.1080/10408398.2016.1180501 Chye, F. Y., Wong, J. Y. \& Lee, J. S. (2008). Nutritional quality and antioxidant activity of selected edible wild mushrooms. Revista de Agaroquimica $y$ Tecnologia de Alimentos 14(4), 375-384. https://doi.org/10.1177\%2F1082013208097445

Colak, A., Kolcuoğlu, Y., Sesli, E. \& Dalman, Ö. (2009). Biochemica composition of some Turkish fungi. Asian Journal of Chemistry 19, 2193-2199. de Wardener, H.E. \& MacGregor, G.A. (2002). Harmful effects of dietary salt in addition to hypertension. Journal of Human Hypertension 16, 213-223. https://doi.org/10.1038/sj.jhh.1001374

Dermirbaş, A. (2001). Concentrations of 21 metals in 1 species of mushrooms growing in the East Black Sea region. Food Chemistry 75, 453-457.

Di Anibal, C., Farenzena, S., Rodri'guez, M.S. \& Albertengo, L. (2015) Chemical composition and nutritional value of Argentine commercial edible mushrooms Journal of Consumer Protection and Food Safety 10, 155-164. https://doi.org/10.1007/s00003-015-0937-9

Djelloul, R. \& Samraoui, B. (2011). Distribution and ecology of the superior mushrooms of the Aulnaie of Ain Khiar (El Kala National Park, Northeastern Algeria). African Journal of Environmental Science and Technology 5(6), 448 456

dos Passos, M.E.A, Moreira, C.F.F., Pacheco, M.T.B., Takase, I., Lopes, M.L.M \& Valente-Mesquita, V.L. (2013). Proximate and mineral composition of industrialized biscuits. Food Science and Technology 33(2), 323-331. http://dx.doi.org/10.1590/S0101-20612013005000046

Edward, J.B., Idowu, E.O., Oso, J.A. \& Ibidapo, O.R. (2013). Determination of heavy metal concentration in fish samples, sediment and water from Odo-Ayo River in Ado-Ekiti, Ekiti State, Nigeria. International Journal of Environmental Monitoring Analysis 1, 27-33. https://doi.org/ 10.11648/j.ijema.20130101.14 Egwim, E.C., Elem, R.C. \& Egwuche R.U. (2011). Proximate composition, phytochemicalscreening and antioxidant activity of ten selected wild edible Nigerian mushrooms. American Journal of Food and Nutrition 1(2), 89-94 https://doi.org/10.5251/ajfn.2011.1.2.89.94

Eyabi, E.G.D. (2001). Understanding the product and process. In: Fellows P Axtell B (eds) A handbook for setting up and running a small food business. Opportunities in food processing series. ACP-EU Technical Centre for Agricultural and Rural Cooperation (CTA), Wageningen, 29-50. 
Falandysy, J., Szymczyk, K., Ichihashi, K., Belawski, L., Gucia, M., Frankowska, A. \& Yamasaki, S.I. (2001). ICP/MS and ICP/AES elemental analysis (38 elements) of edible wild mushrooms growing in Poland. Food Additives and Contaminants 18(16), 503-513.

FAO (2012). West African food composition table. Food Policy Food Nutrition Division, FAO Rome.

Feeney M.J., Dwyer, J., Hasler-Lewis, C.M., Milner, J.A., Noakes, M. Rowes, S., Wach, M., Beelman, R.B., Caldwell, J., Cantoma, M.T., Castlebury, L.A., Chang, S.T., Cheskin, L.J., Clemens, R., Drescher, G., Fulgoni, V.L., Haytowitz, D.B., Hubbard, V.S., Law, D., Myrdal, M.A., Minor, B., Percival, S.S., Riscuta, G. Schneeman, B., Thornsbury, S., Toner, C.D., Woteki, C.E. \& Wu, D. (2014). Mushrooms and health summit proceedings. Journal of Nutrition 144, 1128 1136.

Food and Nutrition Board (2011). Dietary reference intakes for calcium and vitamin D. Institute of Medicine, National Academies. Washington, DC: National Academies Press.

Food and Nutrition Board (2016). Dietary reference intakes for water, potassium sodium, chloride, and sulphate. Institute of Medicine, National Academies. Washington, DC: National Academies Press.

Gbolagade, J., Ajayi, A., Oku, I. \& Wankasi, D. (2006). Nutritive value of common wild edible mushrooms from Southern Nigeria. Global Journal of Biotechnology and Biochemistry 1(1), 16-21.

Grober, U., Schmidt, J. \& Kisters, K. (2015). Magnesium in prevention and therapy. Nutrients 7, 8199-8226. https://doi.org/10.3390/nu7095388

Hemilä, H. (2017). Vitamin C and infections. Nutrients 9(4), 339. https://doi.org/10.3390/nu9040339

Ijioma, B.C., Ihediohanma, N.C., Onuegbu, N.C. \& Okafor, D.C. (2015) Nutritional composition and some anti-nutritional factors of three edible mushroom species in South-Eastern Nigeria. European Journal of Food Science and Technology 3(2), 57-63. https://doi.org/10.13140/RG.2.2.30839.11687

Januškevičius, A. Januškevičienè, G. \& Andrulevičiūtė, V. (2012). Chemical composition and energetic values of selected vegetable species in Lithuanian supermarkets. Veterinarija Ir Zootechnika 58, 8-12.

Jayakumar, T., Thomas, P. A. \& Geraldine P. (2009). In-vitro antioxidant activities of an ethanolic extract of the oyster mushroom, Pleurotus ostreatus. Innovative Food Science and Emerging Technologies 10, 228-234. https://doi.org/10.1016/j.ifset.2008.07.002

Johnsy, G., Sargunam, S. D., Dinesh, M. G. \& Kaviyarasan, V. (2011). Nutritive value of edible wild mushrooms collected from the Western Ghats of Kanyakumari District. Botany Research International 4(4), 69-74.

Jonathan, S. G. (2002). Studies on vegetative growth requirements and antimicrobial activities and antimicrobial activities of higher fungi from Nigeria. $\mathrm{Ph} . \mathrm{D}$. Thesis, University of Ibadan, Nigeria.

Jonathan, S.G., Nwokolo, V.M. \& Ekpo, E.N. (2013). Yield performance of Pleurotus pulmonarius (Fries.) Quelet, cultivated on different agroforest wastes in Nigeria. World Rural Observations 5(1), 22-30.

Kassegn, H.H. (2018). Determination of proximate composition and bioactive compounds of the Abyssinian purple wheat. Food Science and Technology 4 1421415. Kassegn, H.H. (2018). Determination of proximate composition and bioactive compounds of the Abyssinian purple wheat. Food Science and Technology 4, 1421415. https://doi.org/10.1080/23311932.2017.1421415 Kirkland, A.E., Sario, G.L. \& Holton, K.E. (2018). The role of magnesium in $\begin{array}{llll}\text { neurological } & \text { disorders. } & \text { Nutrients } & 10(6)\end{array}$ https://doi.org/10.3390/nu10060730

Knochel, J.P. (1999). Phosphorus. Nutrition in health and disease (9th ed). Baltimore: Williams and Wilkins.

Kowey, P.R. (2002). The role of potassium. In: Lobo, R.A., Crosignani, P.G., Paoletti, R. and Bruschi, F. (eds) Women's Health and Menopause. Medical Science Symposia Series (17). Boston, MA: Springer.

Kožlšek, F. (2003). Health significance of drinking water magnesium and calcium. National Institute of public health. Retrieved April 4, 2019. http://novascotia.ca/nse/water/docs/droponwaterFAQCalciumMagnesium.pdf

Kumar, M. \& Puri, A. (2012). A review of permissible limits of drinking water. Indian Journal of Occupational and Environmental Medicine 16, 40-44. https://doi.org/10.4103/0019-5278.99696

Kumari, B. \& Atri, N.S. (2014). Nutritional and nutraceutical potential of wild edible Macrolepiotoid mushrooms of North India. International Journal of Pharmacy and Pharmaceutical Sciences 6 (2), 200-204.

Maftoun, P., Johari, H., Soltani, M., Malik, R., Othman, N.Z. \& El Enshasy, H.A (2015). The edible mushroom Pleurotus spp.: I. biodiversity and nutritional values. International Journal of Biotechnology for Wellness Industries 4, 67-83. Mattila, P., Könkö, K., Eurola, M., Pihlava, J.M., Astola, J., Vahteristo, L., Hietaniemi, L., Kumpulalainen, J., Valtonen, M. \& Piironen, V. (2001). Contents of vitamins, mineral elements, and some phenolic compounds in cultivated mushrooms. Journal of Agriculture and Food Chemistry 49, 2343-2348. https://doi.org/10.1021/jf001525d

Mattila, P., Suonpää, K. \& Piironen, V. (2000). Functional properties of edible mushrooms. Nutrition 16(7-8), 694-696. https://doi.org/10.1016/s08999007(00)00341-5
Mohan, S., Campbell, N.R.C. \& Willis, K. (2009). Effective population-wide public health interventions to promote sodium reduction. Analysis 181(9), 605609. https://doi.org/10.1503/cmaj.090361

Mshandete, M.A. \& Cuff, J. (2007). Proximate and nutrient composition of three types of indigenous edible wild mushrooms grown in Tanzania and their utilization prospects. Journal of Food, Agriculture, Nutrition and Development 7(6), 230-238.

Musieba, F., Okoth, S., Mibey, R.K., Wanjiku, S. \& Moraa, K. (2013). Proximate composition, amino acids and vitamin profile of Pleurotus citrinopileatus Singer: an indigenous mushroom from Kenya. America Journal of Food Technology 1-7. https://doi.org/10.3923/ajft.2013.200.206

Muthangya, M., Mshandete, A.M., Amana, M.J., Hashim, S.O. \& Amelia K. (2014). Nutritional and antioxidant analysis of Pleurotus HK 37 grown on Agave sisalana saline solid waste International Journal of Research in Biochemistry and Biophysics 4(2), 5-12.

Nakalembe, I., Kabasa, D. \& Olila, D. (2009). Indigenous knowledge and usage of wild mushrooms in Mid-Western, Uganda. African Journal of Animal and Biomedical Science 4 (1), 63-73.

Nakalembe, I., Kabasa, J.D. \& Olila, D. (2015). Comparative nutrient composition of selected wild edible mushrooms from two agro-ecological zones, Uganda. SpringerPlus 4, 433. https://doi.org/10.1186/s40064-015-1188-z

Nasiri, F. Tarzi, B.G., Bassiri, A. \& Hoseini, S. E. (2012). Comparative study on some chemical compounds of button mushrooms (Agaricus bisporus) cap and stipe during the first to third flushes. Annals of Biological Research 3(12), 5677 5680

Nova Scotia Environment (2005). The drop of water calcium and magnesium. Retrieved on April 2019.

http://www.szu.cz/uploads/documents/chzp/voda/pdf/hardness.pdf

Nwordu, M.E., Isu, R.N. \& Ogbadu, G.H. (2013). Catalogue and identification of some wild edible macro-fungi in Nigeria. International Journal of Food Science 2(1), $1-15$

Odebode, S. O. (2005). Contributions of selected non-timber forest products to household food security in Nigeria. Journal of Food, Agriculture and Environment 3, 138-141

Odeyemi, O. \& Adeniyi, M.A. (2015). Ecology and pictorial atlas of Nigerian mushrooms (1st ed.). Ile-Ife, Nigeria: Signet Impressions and Design Ltd.

Odeyemi, O., Adeniyi, M.A. \& Odeyemi, Y. (2014). Introduction to tropical mycology ( $1^{\text {st }}$ ed.) Beijing, China: Universal Academic Press.

Ohnuki, T., Alba, Y., Sakamoto, F., Kozai, N., Niizato, T. \& Sasaki, Y. (2016) Direct accumulation pathway of radioactive cesium to fruit-bodies of edible mushroom from contaminated wood logs. Scientific Report 13, 1194-1214. https://doi.org/10.1038/srep29866

Okhuoya, J.A., Akpaja, E.O., Osemwegie, O.O., Oghenekaro, A.O. \& Ihayere, C.A. (2010). Nigeria mushrooms: underutilized non-wood forest resources Journal of Applied Science and Environmental Management 14 (1), 43-54. https://doi.org/10.4314/jasem.v14i1.56488

Okwulehie, I.C. \& Ogoke, J.A. (2013). Bioactive, nutritional and heavy meta constituents of some edible mushrooms found in Abia State of Nigeria International Journal of Applied Microbiology and Biotechnology Research 1, 7 15. https://doi.org/10.33500/ijambr.2013.01.002

Okwulehie, I.C., Urama, J. \& Okorie, D. O. (2014). Chemical composition and nutritional value of mature and young fruiting-bodies of Pleurotus pulmonarius produced on Andropogon Gayanus straw and Khaya ivorensis sawdust. Journal of Pharmacy and Biological Sciences 9(3), 72-77.

Okwulehie, I.C. \& Odunze, E. (2004). Evaluation of the myco-chemical and mineral composition of some tropical edible mushrooms. Journal of Sustainable Agriculture and Environment 6(2), 157-162.

Olaniyi, A.A. (2000). Essential medicinal chemistry. Ibadan, Nigeria: Shaneson Press.

Olson, R.E. (1999). Water-soluble vitamins. In: Principles of Pharmacology. Edited by Munson, P. L., Mueller, R. A. \& Bresse, G. R. (Chapter 59). New York: Chapman and Hall.

Onuoha, C.I. \& Obi-Adumanya, G.A. (2010). Proximate analysis of Pleurotus tuber-regium (Sing) grown on different substrates. Researcher 2(10), 7-11.

Osemwegie, O.O. \& Okhuoya, J.A. (2009). Diversity of macrofungi in oil palm agroforests of Edo State, Nigeria. Journal of Biological Sciences 9 (6), 584-593. https://doi.org/10.3923/jbs.2009.584.593

Oyetayo, V.O. (2009). Molecular characterisation of Termitomyces species collected from Ado Ekiti and Akure, Nigeria. Nigerian Journal of Microbiology 23(1), 1933-1938

Patil, S.S., Ahmed, S.A., Telang, S.M. \& Baig, M.M.V. (2010). The nutritional value of Pleurotus ostreatus (jacq.:fr.) Kumm cultivated on differen lignocellulosic agro-wastes. Innovative Romanian Food Biotechnology 7, 66-76. Ragunathan., R. \& Swaminathan, K. (2003). Nutritional status of Pleurotus sp. grown on various agro-wastes. Food Chemistry 80, 371-375. https://doi.org/10.1016/S0308-8146(02)00275-3

Rao, A.V. \& Agarwal, S. (2000). Role of antioxidant lycopene in cancer and heart disease. Journal of the American College of Nutrition 19(5), 563-569. https://doi.org/10.1080/07315724.2000.10718953 
Rodri'guez, R., Jime'nez, A., Ferna'ndez- Bolaños, J., Rafael Guille'n, R. \& Heredia, A. (2006). Dietary fibre from vegetable products as a source of functional ingredients. Trends in Food Science and Technology 17, 3-15.

Salano, E.M. (2013). Assessment of heavy metal pollution in soils and water at Samburu county, Kenya. MSc Thesis, Kenyatta University, Kenya.

Sanmee, R., Dell, B., Lumyong, P., Izumori K. \& Lumyong, S. (2003). Nutritive value of popular wild edible mushrooms from Northern Thailand. Food Chemistry 84, 527-532.

Sapers, G. M., Miller, R. L., Choi, S. W. \& Cooke, P. H. (1999). Structure and composition of mushrooms as affected by hydrogen peroxide wash. Journal of Food Science 64(5), 889-892. https://doi.org/10.1111/j.13652621.1999.tb15934.x

Shelley, E. \& Geoffrey, K. (2004). Pocket nature: Fungi. London, UK: Dorling Shelley Evans and Geoffrey Kindersley Limited.

Souci, S.W., Fachmann, W. \& Kraut, H. (2000). Food composition and nutrition tables. 6th ed. Deutsche Forschungsanstalt f ur Lebensmittelchemie, Garching b. M"unchen, Medpharm Scientific Publishing, Stuttgart, Germany. Boca Raton, London, New York, Washington, DC: CRC Press.

Swaminathan, S., Seshadri, M. \& Karagasapathy, A.S. (2011). Effect of tannery effluent on the zinc content of groundwater. Journal of Pharmaceutical and Biomedical Science 11, 1-3.

Thatoi, H. \& Sindevsachan, S.K. (2014). Diversity, nutritional composition and medicinal potential of Indian mushrooms: a review. African Journal of Biotechnology 13(4), 523-545.

Titilawo, Y., Adeniji, A., Adeniyi, M. \& Okoh, A. (2018). Determination of levels of some metal contaminants in the freshwater environments of Osun State, Southwest Nigeria: A risk assessment approach to predict health threat. Chemosphere 211, 834-843. https://doi.org/10.1016/j.chemosphere.2018.07.203

Usha, S. \& Suguna, V. (2014). Investigation on the nutritional value of edible mushrooms viz., Auricularia, Polytricha, and Pleurotus ostreatus. Asian Journal of Science and Technology 5(8), 497-500.

Vetrimurugan, E., Brindha, K., Elango, L. \& Ndwandwe, O.M. (2017). Human exposure risk to heavy metals through groundwater used for drinking in an intensively irrigated river delta. Applied Water Science 7, 3267-3280. https://doi.org/10.1007/s13201-016-0472-6

Wani, H.A., Bodha, R. H. \& Wani, A. H. (2010). Nutritional and medicinal importance of mushrooms. Journal of Medicinal Plants Research 4(24), 2598 2604.

Wardlaw, G.M. \& Kessel, M.W. (2002). Minerals: dietary needs, absorption, transport, and excretion. In: Perspectives in nutrition, 5th ed. Mc Graw-Hill Companies Inc.

Wasser, S. (2002). Medicinal mushrooms as a source of anti-tumor and immunomodulating polysaccharides. Applied Microbiology and Biotechnology 60, 258-274. doi: 10.1007/s00253-002-1076-7.

WHO (2006). Reducing salt intake in populations: report of a WHO forum and technical meeting. Paris, France.

Zoberi, M.H. (1973). Some edible mushrooms from Nigeria. Nigerian Field 38 , $81-90$ 